\title{
Challenges of Early Childhood Care Education in Sustaining Girl-Child Development in Nigeria
}

\author{
Amadi Felicia Ngozi .C. \\ Department of Early Childhood Education \\ Federal College of Education (Technical), \\ Umunze-Nigeria
}

\section{Doi:10.5901/mjss.2013.v4n5p151}

\begin{abstract}
This study was informed by the age-long abandonment of the girl child and denial of her rights and rightful place in the education and overall development of the human race. Evidence has it that the female children are not given equal opportunities for self development and self realization right from inception of life. The Early childhood care Education (ECCE) as constitution in the Nigeria system is perceived as potent instrument that can be used to redress some of the misgivings. The ECCE programme in Nigeria was designed on a sound philosophy as its purpose and role in training of qualified preschool teachers were clearly highlighted. The study made a comprehensive review of the rationale for ECCE constitution and the state of its implementation which as it were, has been disproportionately under the control of less qualified personnel. The challenges of ECCE were identified to include: poor and inconsistent standards across schools, unstimulating learning environments, preponderance of unqualified teachers and care-givers, high cost of education and exploitative and profiteering tendencies on the part of proprietors of ECCE schools/centers. Among the recommended strategies for improving the situation and for giving the girl-child ample opportunity to harness the intended benefits of ECCE included the following; full government control and regulation of establishment and running of ECCE schools/centers; training and retraining of preschool teachers and care-givers through workshops, seminars and conferences, extension of government grants/subventions to privately-owned ECCE schools; establishment of ECCE model schools in rural communities, provision of instructional facilities to ECCE school properties to highly subsidized rates and regular and close monitoring to ensure set standards and conditions are sustained.
\end{abstract}

\section{Introduction}

The case of the neglect of the girl-child and consequent abuse of her right to education and overall development and self realization in Nigeria as in most developing nations of the world is not disputable. This abandonment and abuse has been traced to originate from birth as some men are wont to ignobly abandon their wives in the maternity once it comes to their knowledge that a girl was born to him. This again reels out the long tortuous road the girl-child must sojourn in attempt to survive, first, by being initially denied registration or enlistment into Early Childhood Schools in sheer preference for the boys (Amadi, 2010). It could therefore be contended that even at the very early stage of schooling the girls are generally speaking, not giving a balanced treatment with the boy-counterparts thus, further reducing their rate of integration into the school system and by extension, the society. Amadi (2010) in an earlier study, revealed that even in the ECCE schools, boys and girls are not equally and equitably provisioned as:

1. Parents tend to treat boys specially and

2. Care-givers tend to prefer that the girls take up routine environmental sanitation activities more that the boys who often are left to play as the girls work.

This situation negates the philosophy and ideals of the introduction of the Early Childhood Care Education in Nigeria. 
The Early Childhood Care Education (ECCE) as contained in the National Policy on Education (Federal Republic of Nigeria (FRN), 2004) is the first formal Education for children aged between 2 to 6 years of life in preparation for primary schooling. ECCE was intended to be provided under the care, love, protection and supervision of well-trained and skilled preschool teachers and care-givers. According to Akinola (2004), the ECCE arrangement involves how to teach young child to acquire based knowledge, skills and abilities that will enable them as young children to progress smoothly to primary school level and indeed other levels of education.

Early Childhood Care Education with duration of 3 years requires that children like very tender growing plants are carefully nurtured into stable personalities. This again, demands that requisites facilities and materials be made available for the full and proper engagement of the potentials of the young children. Contributing, Eluwa (1985) contended that the objectives of the ECCE can only realized to the extent that preschool teachers are professionally prepared and humanly disposed in being patient with the kids, avoiding any of shouting with loud voice, scolding or unnecessary flogging as this may seriously interfere with their learning process. Preschool teachers should rather be very friendly, fun-loving, playful and ever-ready in story telling, these being qualities that characterize the preschools ambient environment and which according to Botton (1976), is enjoyed by both normal and physically challenged children. Botton added that at this stage children with handicaps are identified, problems diagnosed for possible remediation. It however depends on a well qualified teacher of the preschooler to effectively take up these challenges. It therefore, requires that preschool teachers are given special training that grooms them to be caring and empathetic, teaching them the rudiments of numbers, letters, shapes, colours as well as inculcate in them social norms and values, spirit of enquiry, inquisition and creativity through play, and to develop a sense of cooperation, team spirit and to acquire good habits in some other socially acceptable dimensions (Akinola, 2004; Amadi, 2010).

Presently, experience has shown that most ECCE teachers and caregivers are everything but professionally qualified for the onerous task entrusted to their care and since no person can give what he or she does not have or posses, a gap imperatively exists between the tasks and responsibilities of the ECCE teacher and his abilities, quality and qualifications consistent with the provisions of the National Policy on Early Childhood Care Education ((Federal Republic of Nigeria (FRN), 2004).

It is believed that the findings and recommendations of this study would go a long way to bettering the lots of all stake holders in the ECCE project in Nigeria. As a matter of fact, with qualified teachers produced in the right quantity manning the various ECCE schools and centers the objectives of the programme are sure to be realized that is, giving a good start to Nigeria children of whatever sex, religious, ethnic origin and what have you. The government would have invested profitably and meaningfully in the education of her citizenry by taking care of a once- neglected stratum of the society upon which the future youths and adult citizenry are founded.

\section{Place of Early Childhood Care Education in the Nigeria Socio-Economic Paradigm.}

Early Childhood Education experiences have so far proved to be useful in providing children with high sense of security, welfare and physical love while their parents are at work. Such parents no doubt, have peace of mind each time they remember that their children are in safe hands. Supporting the above claim, Acho (1992) indicates that ECCE provides children the opportunity to interact with teachers and peers and for playing with their mates. By this process children are capable of developing good language skills, numeracy skills and social habits for effective communication needed now and in later stages of life. Through observation, imitation and modeling, preschoolers with the advantage of ECCE are able to develop early concepts in the fields of science and technology as they play with their toys and other instructional gadgets such as computer-based simulated experiences and games. 
They indeed, are exposed to variables that conduce effective cognitive development through appropriate and suitable experiences preparing and predisposing them to good speaking, listening, reading and writing and most importantly, preparing them for transition into the primary level of education. In line with the Nigerian's Philosophy of Education which stresses that every child be given equal educational opportunities irrespective of gender or any form of discrimination, the philosophy of the Early Childhood Care Education (ECCE) aims to ensure that the needs of every child-be it social, physical, emotional, mental or psychological - is catered for. Added to this is the need to protect them from physical injury, malnourishment, diseases as well as all forms discrimination.

The Early Childhood Care Education Curriculum is therefore child-centered and activity-based. It therefore, follows logically that the educational objectives and learning experiences must be organized around activities that will encourage every child the opportunity to realize his/her full potentials. To this end, learning environments must be interactive and conducive to learning as much as instructional materials provision could guarantee. Teachers should be attuned to the use of effective and appropriate instructional methods and techniques that can always accommodate the differential learning styles of every preschooler.

The teaching of preschoolers demands that they be properly motivated, ensure an effective feedback mechanism and guidance services required to take care of individual differences in areas of disabilities and special abilities ((Federal Republic of Nigeria (FRN), 2004). The Nigeria's experience as provided in the ECCE Policy demands that learning packages be carefully planned and delivered to take care of the variant needs, materials and aspirations of the children. By so doing, the average Nigerian child will be capable of developing into a good and responsible citizen willing to make useful contribution to the development of his/her society.

\section{Origin, Objectives, and Rationale for the Introduction of ECCE into Nigeria's Education System.}

The ECCE project is definitively positioned to address the following objectives ((Federal Republic of Nigeria (FRN), 2008)

- Effecting a smooth transition from home to the school

- Preparing the child for the primary level of education

- Providing adequate care and supervision for the children while their parent are at work (on the farm, in the market, office e.t.c)

- Inculcating social norms and values

- Inculcating in the child the spirit of inquiring and creativity through the exploration of nature, the environment, art, music and playing with toy. e.t.c.

- Developing in the children a sense of cooperation and team-spirit.

- Learning good habits and the rudiments of letters, numbers, colours, shapes and forms e.t.c.

These are laudable objectives that can only be realized if the curriculum is prosecuted by specialist teachers equipped with in-depth knowledge of child psychology and pedagogical skills to know what to do and at the right time. (Akinola, 2004). The spirited efforts to formally launch Early Childhood Care Education through solid policy frameworks could be situated in the Global (United Nations) plan of protecting the rights of the child. Obisanya (2001) opines that this forward thrust was occasioned by the barrage of national and international conventions on child's right protection. Okunrotifa (1977) argues that from birth to age of 6 years children develop half of their intelligence that they would use in adulthood. Similarly, Bloom (1964) posits that the first 6 years of life in critical to the development of all cognitive accessories useful in later stages of life. From those psychological and philosophical perspectives of Bloom (1964) and Okunrotifa (1977) the launch and/or re-launch of Early Childhood Care Education is objectively justified. 


\section{Early Childhood Care Education from Historical perspective.}

The advent of the Early Childhood Education can be traced back to the era of Nigeria independence in they year 1960 when the colonial masters established some pre-primary schools to cater for their preschool-age children, though few children of Nigerian elites benefit too (Afe, 1992). As further informed by Afe (1992) the introduction of the University (free) Primary Education (UPE) in 1976 was another factor that consolidated pre-primary schooling since with more boys and girls enrolled into primary schools, living of house-helps suffered a serious setback. This development inadvertently led to the establishment of Day-care centres in some cities by private individuals and churches. Matterson (1978) reported that some few Nigerians who travelled abroad came in contact with international organizations like UNESCO and UNICEF which not only broadened their perception about children educational needs but also made them to realize the importance of education for future development. The situation led to the initial attempt to include Early Childhood Care Education in the National Educational Policy enunciated by the federal government in 1981((Federal Republic of Nigeria (FRN), 2008).

\section{Challenges of Early Childhood Care Education in Nigeria.}

One of the major challenges confronting Early Childhood Care Education in Nigeria is that of unqualified, illequipped teachers and care-givers (Amadi, 2010). Most of these schools employ secondary school dropouts as teachers with the most qualified of the teachers being holders of Teachers Grade II certificate. Corroborating the above claim Eresimadu (1998), reveals that before the recent developments there were no pre-primary teacher education programmes to prepare teachers for the level particularly with the phasing out of the TC II programme.

\section{Government non participation in pre-primary Education}

The government in spite of its efforts to set up policy framework for ECCE has not demonstrated enough commitment in terms of funding, monitoring and evaluation as well as establishment and management of ECCE schools the bulk of which still belongs to private investors whose main objective in profit making. Eresimadu (1998) opines that the government has failed to assist the private sector in the establishment and management of pre-primary schools, provision of facilities and teaching aids it only provides policy guidelines he concluded.

\section{Inadequacy of Space and Equipment.}

Facilities such as classrooms, libraries, staff, laboratories, and furniture are grossly inadequate in a greater number of the ECCE schools. (Eresimadu \& Eze, 1998). In use are uncompleted buildings, makes shifts and car garages that are poorly ventilated most of which have only mats as furniture. This situation can never guarantee effective teaching and learning of these tenderlings whose lives are further jeopardized.

\section{Poor Teaching Methods and Materials}

In pre-school Teaching, toys, diagrams, charts, pictorials e.t.c are invaluable instructional requirements that are lacking in most of the ECCE schools presently. Decrying the pathetic state of implementation of ECCE curriculum, Maduewesi (1998) blamed the sustained use of poor teaching methods on government's lip service as indicated in poor supervision by the ministry of Education and absence of well-planned teaching modules. Although it was recommended in the National Policy on Education (1987and 2004) that the state ministries of education should monitor the establishment and management of pre-schools, Amadi (2010) in 
his study revealed that quality is always compromised as these officials are "sorted" out with huge sums of money leaving the innocent children at the mercy of charlatans. Lending their support to this revelation, Adenokun and Okhaware (1996) revealed the inability of state arm of government to provide the required checks and balances. Hence they recommended regular supervision and inspection of the schools and workshops for proprietors.

\section{Early Childhood Care Education and Development of Girl-child in Nigeria}

One may be compelled to inquire the relationship between ECCE and development of the girl-child. The early childhood children of today are the youths and adults of tomorrow, and since the youth-age or adolescence is very critical in the life of every human, a period when most vices and crimes of the society are groomed, nurtured and executed by, it becomes imperative to bridge gaps that could be prelude to their development. The girl-child has been vulnerable, as both a victim and perpetrator of such social vices as she is denied opportunities for self expression, and the society is worse for it. ECCE comes in to assuage the situation and to give the girl-child a good start in life that will certainly open for her brighter gateways for a more meaningful, value-oriented future life. With the acquisition of basic life survival skills, children of the early childhood age would gradually and with consistency of purpose by the education system develop into responsible citizens.

\section{Recommendations}

As a way of re-orienting Early Childhood Care Education and for the girl-child to take the derivable advantages of quality early education the following recommendation are made:

- The current government emphasis on ECCE through the provisions of National Policy on Education should be sustained. To this effect, ministries of Education in the states should be reorganized to brace up with the responsibility of quality control in the schools.

- Schools should be licensed to operate for ECCE only upon the satisfaction of prescribed quality guidelines including minimum infrastructural requirements.

- Teachers and care-givers should endeavour to treat children with the desired equity irrespective of gender or other wanton variables.

- Parents should be encouraged to treat every child with respect for his/her right to live and the dignity of humanity -all children are born equals.

- Government subvention should be extended to private ECCE schools/proprietors as a way of ensuring moral commitment of the government in the regulatory activities.

- Model ECCE schools should be set up in rural communities under the auspices of the Local Government Education Authorities (LGEAs).

- Importation of ECCE instructional facilities should be duty-free and or worst still, at a highly subsidized rate of duties.

- A special salary/emolument package for ECCE teachers and care-givers should be put in place so as to attract and retain well qualified teachers.

\section{Conclusion}

Early Childhood Care Education is a necessity in the life of every child therefore; every child should be given the opportunity for this exposure to a good learning environment which ECCE stands to provide. The girlchild particularly, should enjoy this as her inalienable right. 


\section{References}

Adenokun, A.\& Okhaware, P. (1996): A critical assessment of Pre-primary school in Kontagora Local Government Area of Niger state. Minna, Beagle Publishing Company.

Afe, J.O. (1992): Studies of Cognitive development in Early Childhood. In Emenogu, B.C., Okoro O.V.N, Ofoefuna, M.O. \& Nweze G.C.(eds). Issues and Strategies in Childhood Education. Onitsha; Hybrid Publishers.

Akinola, B.M.A. (2004): The place of Pre-primary Education in Nigeria National Policy Education. Nigerian Journal of Educational Studies and Research (NJESR) 2 (25).

Amadi, U.P.N .(2010): Quality Control in Privately-owned Nursery and Primary schools in Anambra state. A commissioned paper presented at the Annual workshop of proprietors of privately owned Nursery/primary schools held at the Seat of Wisdom Schools Nnewi 6 - $8^{\text {th }}$ August

Bloom, B.S. (1964): Stability and Change in Human Characteristics. New York; John Wiley.

Botton. E. (1976): Parents and Nursery schools. Study Bulletin of Institution of study, University of Toronto $\underline{29}$ (2-4)

Eluwa, M.C. (1985): Pre-primary Education and the National Policy on Education. A Commissioned paper presented at the National workshop on the National Conference of Nigeria, Nsukka, 12-16 February

Eneasator, G.O. (1992): Implementation of pre-primary Education Policy in Nigeria: A Case study of Anambra state.Onitsha; Hybrid publishers Nigeria Ltd.

Eresimmadu, F.N.J. (1998): Management of Nursery staff personnel in Anambra state: problems and prospects. In Igboabuchi, B.O. \& Eze, D.O. (eds) Pre-primary Education in Nigeria. Conference proceedings.

Federal Republic of Nigeria (FRN, 2008): The National Policy on Education. Lagos, National Educational Research and Development centre (NERDC).

Igboabuchi, D.O. \& Eze D.O. (1998). Pre-primary Education in Nigeria. Conference Proceedings. Onitsha; Linncel publication.

Maduewesi, E.J. (1998): Early Childhood Education in Nigeria. In Igboabuchi B.O \& Eze, D.O (eds) Pre-Primary Education in Nigeria. Conference Proceedings. Onitsha, Lincel publishers.

Matterson, E.M. (1978): Play with a purpose for Under-seven. London/Great Britains, poguem Books.

Obisanya, O.O. (2001): An Evaluation of the Child care Development and Education project in Nigeria.(unpublished) PhD Thesis of the University of Ibadan.

The New Encyclopedia Brifanica (1998): Chicago Encyclopedia Britannica Inc 